\title{
First report of Epibiont ciliates (Ciliophora: Peritrichia) living in Brinkhurstia americanus (Oligochaeta: Alluroididae) in a Neotropical river
}

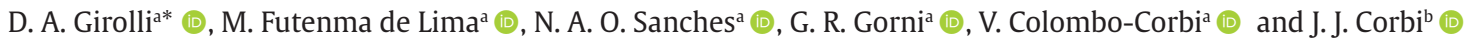 \\ a Universidade de Araraquara - UNIARA, Programa de Pós-graduação em Desenvolvimento Territorial e Meio Ambiente, Araraquara, SP, Brasil \\ ${ }^{\mathrm{b}}$ Universidade de São Paulo - USP, Escola de Engenharia de São Carlos - EESC, Departamento de Hidráulica e Saneamento, São Carlos, SP, Brasil
}

A considerable part of the ciliates are free-living protists, in water and soil. Some groups have parasitic, commensal or symbiont species (Verni and Gualtieri, 1997). The latter characterizes the term "epibiont". According to Martins (2018), epibiont ciliates may prefer localization sites in their host (or basibiont) that satisfy their ecological needs. Wahl (1989) points that this biological interaction can involve advantages and disadvantages for epibionts and basibionts, as both have their morphological, physiological, and behavioral adaptations. The adverse consequences of epibiosis on the host may include a decrease in survival ability and perturbation of movement (Henebry and Ridgeway, 1979). Epibiosis can be considered beneficial for epibiont, which can be moved to areas abundant in food or more oxygenated regions, as pointed out by Regali-Seleghim and Godinho (2004). As suggested by Liu and Gong (2012), peritrichs are a varied, ecologically significant ciliate group generally with a complex life cycle (Liu and Gong, 2012). This interaction in the aquatic macroinvertebrate community was described by Dias et al. (2007), who recorded the ciliate Rhabdostyla chironomi on the abdominal tubules of chironomid larvae (Diptera: Chironomidae), relating the location of the ciliate to the ventilation behavior exhibited by host, which vibrates the respiratory tubules to increase gas exchange. Smith (1986), observed a great number of epibiontic ciliates in the posterior region of Dero nivea (Oligochaeta: Naididae), attributing to the ventilation generated by the gills of these organisms. On the other hand, the regions of greatest friction in the hosts are avoided by the ciliated protists and can influence the occurrence in specific sites on the basibionts (Green, 1974; Utz and Coats; 2005). Utz and Coats (2005) observed low densities of ciliate in the antennae and legs of copepods, due to the great mobility of these regions. Epibiont ciliates have also been recorded in association with other basibiont organisms such as cladocerans (Green, 1974; Martins, 2018), isopods (Clamp, 1988; Azevedo et al., 2014), gastropods of the family Ampullariidae (Dias et al., 2008), plecopteros (Silva, 2010), chironomid larvae (Dias et al., 2007; Cabral et al., 2010), Leptophlebiidae (Ephemeroptera)
(Abrahão et al., 2017), Odonata larvae (Corbi et al., 2016) and Annelids (Oligochaeta) (Dias et al., 2009).

Here, we report a first record of epibiont ciliates (Ciliophora: Peritrichia) associated with Brinkhurstia americanus Brinkhurst, 1964 (Oligochaeta: Alluroididae) (Figure 1). The study was conducted in the Juruena River, located in the State of Mato Grosso, Brazil $\left(13^{\circ} 22 \mathrm{~S}\right.$ and $59^{\circ} 00 \mathrm{~W}$ ). The sampling was performed on July/2012, in macrophytes banks (sublittoral region) using a D-net sampler, with $0.30 \mu \mathrm{m}$ mesh. According to Gorni et al. (2018), the sampling sites are free from anthropogenic disturbances. The collected samples were fixed in $10 \%$ formaldehyde and preserved in $70 \%$ alcohol. For the Oligochaeta identification, taxonomic criteria adopted by Brinkhurst and Jamieson (1971), Righi (1984), Brinkhurst and Marchese (1989), were followed.

In general, epibiosis is seen as a commensal relationship (Azevedo et al., 2014). In this case, no negative relation seems to be offered to $B$. americanus, since the epibiontic ciliates are in the posterior region of the oligochaete. Site predilection on the host is a characteristic of species that form epibiotic communities and can reveals the ecological requirements of the epibiont (Fernandez-Leborans et al., 1997; Dias et al., 2009). A study conducted by Dias et al. (2009) analyzed site preference and patterns of spatial and temporal occurrence of ciliate protists on limnic oligochaetes Limnodrilus hoffmeisteri. In that study, the authors analyzed the possible causes of the abundance of epibionts in the posterior region of the Oligochaeta and pointed out that this relationship may be a result of three ecological needs of the ciliates: food availability, and an oxygenated locale with less friction. Additional observations of ciliates living in oligochaetes of the families Tubificidae, Lumbriculidae and Naididae has previously been recorded (see Dias et al., 2009). As pointed out by Henebry and Ridgeway (1979) and Zingel et al. (2007), epibiont ciliates consume mainly bacteria, and their location in the host's body is indifferent. However, adhesion to the prostomial region would probably make the establishment of epibionts unfeasible due to friction caused by movements, as also be pointed by Fernandez-Leborans et al. (1997); Utz

*e-mail: douglasgirolli@gmail.com

Received: March 10, 2020 - Accepted: August 4, 2020

This is an Open Access article distributed under the terms of the Creative Commons Attribution License, which permits unrestricted use, distribution, and reproduction in any medium, provided the original work is properly cited. 


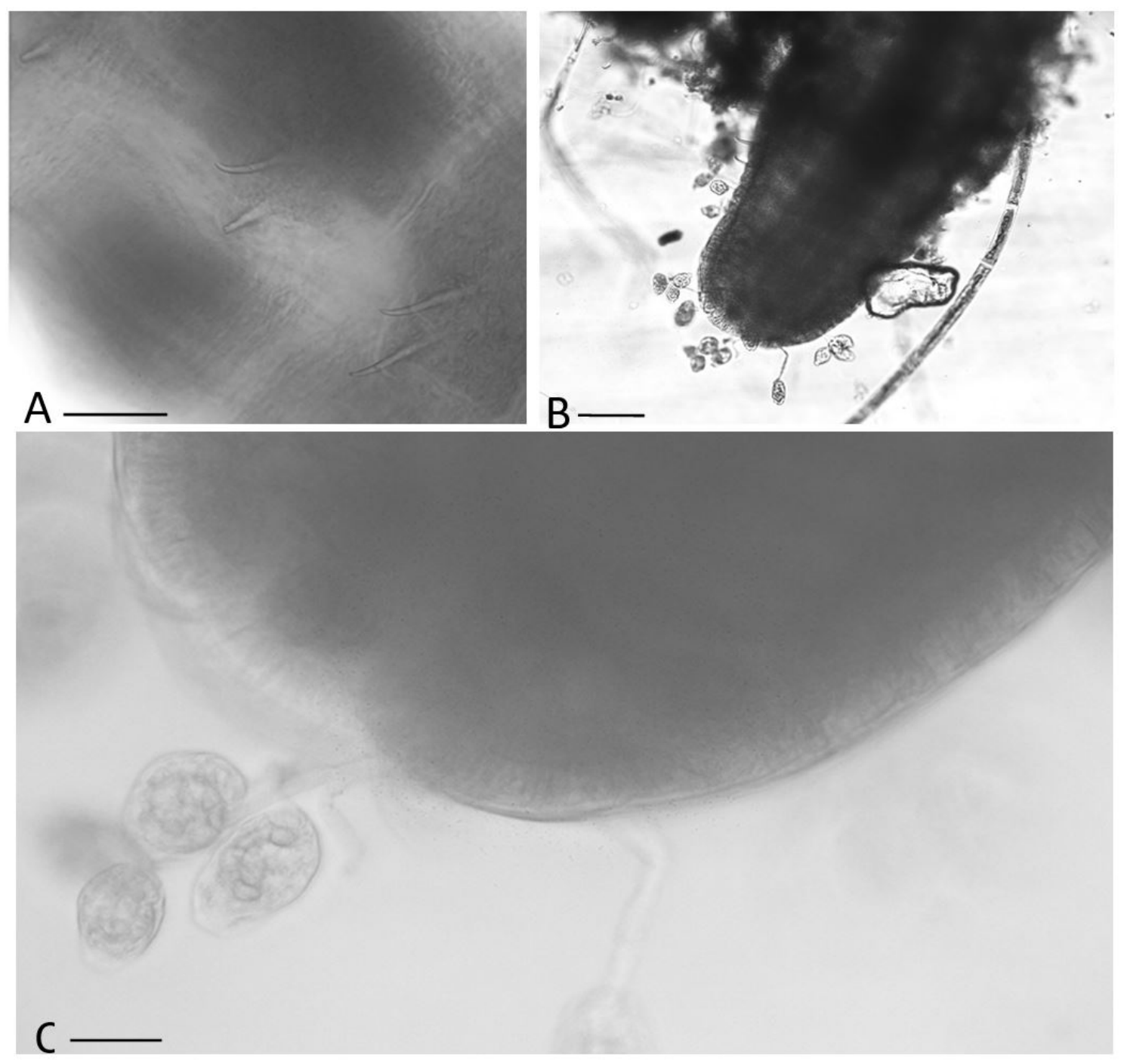

Figure 1. Brinkhurstia americanus. (A) Anterior ventral chaetae; (B) epibiont ciliates associated in the posterior region; and (C) epibiont ciliates. Scale bars: (A) and (B) $100 \mu \mathrm{m}$; (C) $10 \mu \mathrm{m}$.

and Coats (2005); Dias et al., (2009). Consequently, our observations may be related to the preference of an adhesion surface or to a basibiont that provides ideal conditions for the survival required by epibiont ciliates.

\section{References}

ABRAHÃO, D.P., MELLO, J.L., GORNI, G.R. and CORBI, J.J., 2017. First report of Epibiont ciliates (Ciliophora: Peritrichia) living on larvae of Leptophlebiidae (Ephemeroptera) from Brazil. Brazilian Archives of Biology and Technology, vol. 60, no. 0, pp. e17160294. http://dx.doi.org/10.1590/1678-4324-2017160294.

AZEVEDO, R.K., BRANDÃO, H., ABDALLAH, V.D. and SILVA, R.J., 2014. First record of an epibiont protozoan Epistylis sp. (Ciliophora, Peritrichia) attached to Ergasilus chelangulatus (Ergasilidae) in Brazil. Brazilian Journal of Biology = Revista Brasileira de Biologia, vol 74, no. 2, pp. 460-463. http://dx.doi.org/10.1590/1519-6984.10112. PMid:25166331.
BRINKHURST, R.O. and JAMIESON, B.G.M., 1971. Aquatic Oligochaeta of the world. Toronto: University of Toronto Press, $860 \mathrm{p}$.

BRINKHURST, R.O. and MARCHESE, M.R., 1989. Guia para la identificación de oligoquetos acuáticos continentales de Sud y Centroamerica. Santa Fé: Asociación de Ciências Naturales del Litoral, 207 p.

CABRAL, A.F., DIAS, R.J.P., UTZ, L.R.P., ALVES, R.G. and D'AGOSTO, M., 2010. Spatial and temporal occurrence of Rhabdostyla cf. Chironomi Kahl, 1933 (Ciliophora, Peritrichia) as an epibiont on chironomid larvae in a lotic system in the neotropics. Hydrobiologia, vol. 644, no. 1, pp. 351-359. http://dx.doi.org/10.1007/s10750-010-0202-2.

CLAMP, J.C., 1988. A new species of Lagenophrys (Ciliophora: Peritricha: Lagenophryidae) ectocommensal on the woodboring isopod Limnoria (Flabellifera: Limnoridae). Transactions of the American Microscopical Society, vol. 107, no. 1, pp. 12-16. http://dx.doi.org/10.2307/3226400.

CORBI, J.J., ABRAHÃO, D.P., MELLO, J.L.S. and GORNI, G.R., 2016. Record of Epibiont ciliates (Ciliophora: Peritrichia) living on larvae of Odonata from Brazil. Brazilian Journal of Biology = 
Revista Brasileira de Biologia, vol. 77, no. 2, pp. 417-419. http:// dx.doi.org/10.1590/1519-6984.19115. PMid:27579979.

DIAS, R.J.P., CABRAL, A.F., MARTINS, R.T., STEPHAN, N.N.C., SILVANETO, I.D., ALVES, R.G. and D'AGOSTO, M., 2009. Occurrence of peritrich ciliates on the limnic oligochaete Limnodrilus hoffmeisteri (Oligochaeta, Tubificidae) in the neotropics. Journal of Natural History, vol. 43, no. 1-2, pp. 1-15. http://dx.doi. org/10.1080/00222930802478644.

DIAS, R.J.P., CABRAL, A.F., STEPHAN, N.N.C., MARTINS, R.T., SILVANETO, I.D., ALVES, R.G. and D'AGOSTO, M., 2007. Record of Rhabdostyla chironomi Kahl, 1933 (Ciliophora, Peritrichia) Epibiont on Chironomidae larvae (Diptera, Chironomidae) in a lotic sytem in Brazil. Brazilian Journal of Biology = Revista Brasileira de Biologia, vol. 67, no. 4, pp. 783-785. http://dx.doi.org/10.1590/S1519-69842007000400030. PMid:18278337.

DIAS, R.P.J., D’ÁVILA, S., WIELOCH, A.H. and D’AGOSTO, M., 2008. Protozoan ciliate epibionts on the freshwater apple snail Pomacea figulina (Spix, 1827) (Gastropoda, Ampullariidae) in an urban stream of south-east Brazil. Journal of Natural History, vol. 42, no. 19-20, pp. 1409-1420. http://dx.doi. org/10.1080/00222930802007831.

FERNANDEZ-LEBORANS, G., CÓRDOBA, M.J.H. and DEL ARCO, P.G., 1997. Distribution of ciliate epibionts on the portunid crab Liocarcinus depurator (Decapoda: brachyura). Invertebrate Biology, vol. 116, no. 3, pp. 171-177. http://dx.doi. org/10.2307/3226894.

GORNI, G.R., SANCHES, N.A.O., COLOMBO-CORBI, V. and CORBI, J.J., 2018. Oligochaeta (Annelida: Clitellata) in the Juruena River, MT, Brazil: species indicators of substrate types. Biota Neotropica, vol. 18, no. 4, pp. 1. http://dx.doi.org/10.1590/16760611-bn-2018-0566.

GREEN, J., 1974. Parasites and epibionts of Cladocera. Transactions of the Zoological Society of London, vol. 32, no. 6, pp. 417-515. http://dx.doi.org/10.1111/j.1096-3642.1974.tb00031.x.

HENEBRY, M.S. and RIDGEWAY, B.T., 1979. Epizoic ciliated protozoa of planktonic Copepods and Cladocerans and their possible use as indicators of organic pollution. Transactions of the American Microscopical Society, vol. 98, no. 4, pp. 495-508. http://dx.doi. org/10.2307/3225899.
LIU,X. and GONG, J., 2012. Revealing the diversity and quantity of peritrich ciliates in environmental samples using specific primer-based PCR and quantitative PCR. Microbes and Environments, vol. 27, no. 4, pp. 497-503.http://dx.doi.org/10.1264/jsme2.ME12056.PMid:23100023.

MARTINS, L.H.H., 2018. Estudo da influência da epibiose do protozoário ciliado Epistylis pygmaeum Ehrenberg, 1838 sobre o zooplâncton. São Carlos: Universidade Federal de São Carlos, 116 p. Tese de Doutorado em Ecologia e Recursos Naturais.

REGALI-SELEGHIM, M.G. and GODINHO, M.J.L., 2004. Peritrich epibiont protozoans in the zooplankton of a subtropical shallow aquatic ecosystem (Monjolinho Reservoir, São Carlos, Brazil). Journal of Plankton Research, vol. 26, no. 5, pp. 501-508. http:// dx.doi.org/10.1093/plankt/fbh055.

RIGHI, G., 1984. Manual de identificação de invertebrados límnicos do Brasil. Brasília: CNPq/Coordenação Editorial, 48 p.

SILVA, F.A.C., 2010. Plecoptera (Insecta) em riachos da Estação Biológica de Santa Lúcia, Espírito Santo, Brasil: distribuição espacial, sazonal e preferência por substrato. Seropédica: Instituto de Biologia, Universidade Federal Rural do Rio de Janeiro, 59 p. Dissertação de Mestrado em Biologia Animal.

SMITH, M.E., 1986. Distribution patters and sazonal occurence of Rhabdostyla sp. (Peritrichia: Epistylididae) on Dero nivea (Oligochaeta: Naididae). American Midland Naturalist, vol. 116, no. 2, pp. 348-355. http://dx.doi.org/10.2307/2425743.

UTZ, L.R.P. and COATS, D.W., 2005. Spatial and temporal patterns in the occurrence of peritrich ciliates as epibionts on calanoid copepods in the Chesapeake Bay, USA. The Journal of Eukaryotic Microbiology, vol. 52, no. 3, pp. 236-244. http://dx.doi.org/10.1111/ j.1550-7408.2005.00025.x. PMid:15927000.

VERNI, F. and GUALTIERI, P., 1997. Feeding behavior in ciliated protists. Micron, vol. 28, no. 6, pp. 487-504. http://dx.doi. org/10.1016/S0968-4328(97)00028-0.

WAHL, M., 1989. Marine epibiosis. I. Fouling and antifouling: some basic aspects. Marine Ecology Progress Series, vol. 58, pp. 175189. http://dx.doi.org/10.3354/meps058175.

ZINGEL, P., AGASILD, H., NOGES, T. and KISAND, V., 2007. Ciliates are the dominant grazers on pico and nanoplankton in a shallow, naturally highly eutrophic lake. Microbial Ecology, vol.53, no. 1, pp. 134-142. http://dx.doi.org/10.1007/s00248-006-9155-4. PMid:17186145. 